\title{
Structural, ultrastructural and immunohistochemical evidence of testosterone effects and its ablation on the bulbourethal gland of the Artibeus planirostris bat (Chiroptera, Mammalia)
}

\author{
Cíntia C.I. Puga ${ }^{a}$, Mateus R. Beguelini ${ }^{b}$, Eliana Morielle-Versute ${ }^{c}$, Patricia S.L. Vilamaior ${ }^{a}$, \\ Sebastião R. Taboga ${ }^{\mathrm{a}, *}$ \\ a Department of Biology, UNESP-Universidade Estadual Paulista, São José do Rio Preto, São Paulo, Brazil \\ ${ }^{\mathrm{b}}$ Center of Biological and Health Sciences, UFOB-Universidade Federal do Oeste da Bahia, Barreiras, Bahia, Brazil \\ ${ }^{c}$ Department of Zoology and Botany, UNESP-Universidade Estadual Paulista, São José do Rio Preto, São Paulo, Brazil
}

\section{A R T I C L E I N F O}

\section{Article history:}

Received 20 May 2016

Received in revised form 18 May 2017

Accepted 4 June 2017

Available online 14 June 2017

\section{Keywords:}

Bat

Castration

Hormone supplementation

Testosterone

Bulbourethral gland

\begin{abstract}
A B S T R A C T
This study evaluated the effects of testosterone in the bulbourethral glands (BG) of the bat, Artibeus planirostris, by performing castration and posterior hormonal supplementation of the animals. The results showed a decrease in testosterone levels in animals 15 days after castration, which induced a small reduction in epithelium height, percentage of AR+ cells, and an increase in the amount of basal cells. This reduction became more severe in groups castrated for longer periods (19 and 22 days), where there was also an increase in apoptotic cells. Moreover, the hormonal supplementation increased testosterone levels (after 3 and 7 days of supplementation), causing a glandular reactivation that increased the epithelium height and AR expression. In conclusion, BG took longer to respond to ablation of testosterone than other reproductive glands, since it showed evident aspects of regression only in animals 22 days after castrated.
\end{abstract}

(c) 2017 Elsevier Ltd. All rights reserved.

\section{Introduction}

The bulbourethral gland (BG), one of the reproductive accessory glands, is important in male reproductive functions in mammals. The secretion of these glands usually cleans urine from the urethra, and subsequently helps in the lubrication of the vagina, as it is released before ejaculation (Samuelson, 2007).

The BG structurally differs in different species of mammals. It is completely absent in moles (Racey, 1978), dogs and aquatic mammals (Dyce et al., 2002), is poorly developed in humans (Jequier, 1995), but well developed in the pig (Badia et al., 2006). The morphology of the BG has been studied in various mammals, especially rabbits and rodents such as hamster, rat, chinchillas and the cane rat (Adaro et al., 2001; Adebayo et al., 2015; Cakir and Karatas, 2004; Jesik et al., 1982; Toma and Buzzell, 1988; Vasquez and Del Sol, 2002).

Despite there being only a few studies about the reproductive glands of bats, Puga (2011), Puga et al. (2013), Martins et al. (2015)

\footnotetext{
* Corresponding author at: Rua Cristóvão Colombo n 2265, Jardim Nazareth, 15054-000, São José do Rio Preto, São Paulo, Brasil.

E-mail address: taboga@ibilce.unesp.br (S.R. Taboga).
}

and Christante et al. (2015) observed that, macroscopically, the BG of Artibeus planirostris, Platyrrhinus lineatus and Molossus molossus, respectively, is an oval-shaped acinar gland, which was partially surrounded by muscular tissue and contained a columnar epithelium with basal nuclei. The columnar epithelial cells were filled with many secretory droplets of variable electron density, which are released at the apex of the epithelium, where there are small projections of the cell membrane.

The literature related to the influence of androgens in the reproductive glands is always related to the prostate gland. These studies show that surgical castration causes an abrupt and significant decrease in serum androgen levels and a reduced blood flow to the prostate, which induces apoptosis in endothelial and secretory cells (Kyprianou and Issacs, 1988; Shabisgh et al., 1999). After castration, the epithelium regresses, but the epithelial cells remain sensitive to androgens. Thus, testosterone replacement regenerates the prostatic epithelium by restoring the function and number of normal cells (Risbridger et al., 2001).

There are few studies related to the effects of castration on BG, with these showing different responses among mammals. Aykroyd and Zuckerman (1938) showed that there was regression only in the peripheral part of the BG of mature male rhesus monkeys, which had been castrated five months earlier. Similarly, apud Aykroyd and 


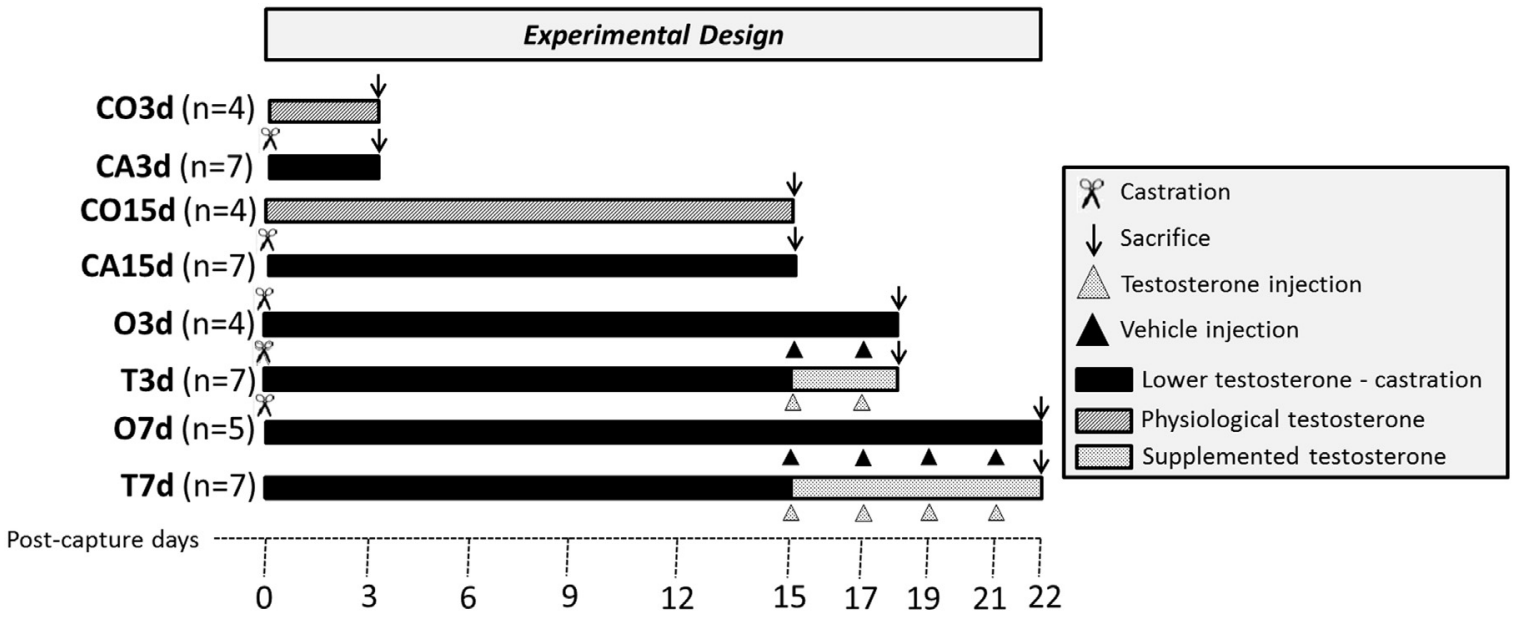

Fig. 1. Schematic representation of the experimental design used in this study.

Zuckerman (1938) noticed little regression in the first year after castration in guinea pigs. On the other hand, these results are very different from those found in rats (Heller, 1932), which show quick and marked changes post-castration.

While it is known that tropical bats have morphological patterns and reproductive characteristics close to the general pattern of mammals, studies have shown that some species have unique characteristics. For example, Myotis nigricans varies in activity geographically: in Mexico, it has hibernating pattern, whereas in Paraguay, it is active all year (Wilson and Findley, 1970, 1971), and in Brazil, it presents two peaks of intense spermatogenic activity followed by two periods of testicular regression (Beguelini et al., 2012). Moreover, in tropical species, such as Eptesicus furinalis, Histiotus velatus, Lasiurus blossevillii and $M$. nigricans, which do not hibernate yet they present testicular regression and sperm storage in the cauda epididymis throughout the year (Beguelini et al., 2012). There are also species that show great asynchrony between the functions of the testis and epididymis, and the reproductive accessory glands functions; for example, Taphozous georgianus (Jolly and Blackshaw, 1987).

Thus, based on the conflicting relationship of the BG with testosterone in mammals, and the wide variation in reproductive patterns of bats, the aim of this study was to evaluate the effect of testosterone in the BG of $A$. planirostris, through castration and posterior hormone supplementation.

\section{Materials and methods}

\subsection{Species, ageing and experimental design}

The species analyzed was Artibeus planirostris (Spix, 1823), which is an exclusively Neotropical species of phyllostomid bat that is not listed as endangered on the International Union for Conservation of Nature (IUCN) Red List of Threatened Species.

The bats were identified as adult aged based on body weight, complete ossification of the metacarpal-phalangeal epiphyses, wear of the teeth (Knegt et al., 2005), positioning of the testes and the presence of sperm inside the testes, cauda epididymis and/or urethra (Puga et al., 2013, 2014; Beguelini et al., 2013a, 2013b, 2014a, 2014b).

Artibeus planirostris is a wild species that is protected by federal laws in Brazil (IBAMA). In addition, its harem structure (with a single male mated to multiple females) means that the collection of male specimens directly influences the structure and dynamics of the populations. Thus, the number of specimens used in this study was the maximum number obtained from a balance between the minimum number required for relevant statistical analyses and the maximum number of individuals that could be collected without destroying or disrupting the colonies of bats.

Thus, 46 sexually mature male specimens were analyzed. Eight groups were formed (Fig. 1): I) 3 day control (CO3d, n=4); II) 3 day castration (CA3d, $n=7$ ); III) 15 day control (CO15d, $n=5$ ); IV) 15 day castration (CA15d, $n=7)$; V) 15 day castration with injection of mineral oil for 3 days ( $\mathrm{O} 3 \mathrm{~d}, \mathrm{n}=4)$; $\mathrm{VI}) 15$ day castration with testosterone cypionate $(1 \mu \mathrm{g} / \mathrm{kg} /$ day) supplementation for 3 days (T3d, $\mathrm{n}=7$ ); VII) 15 day castration with injection of mineral oil for 7 days $(\mathrm{O} 7 \mathrm{~d}, \mathrm{n}=5)$; and VIII) 15 day castration with testosterone cypionate $(1 \mu \mathrm{g} / \mathrm{kg} /$ day) supplementation for 7 days (T7d, $\mathrm{n}=7$ ). The administration route of testosterone or mineral oil was intramuscular.

\subsection{Study area, capture and licenses}

The animals were collected in the city of São José do Rio Preto, in the northwest of São Paulo State, Brazil, (49W22'45", 20S49'11"), which is located $500 \mathrm{~m}$ above sea level. This is a semi-flat region, set in a degraded Cerrado biome, with a meso-thermal climate (rainy summers and dry winters).

The captures were conducted in the summer (21st December to 21st March) in order to minimize variations arising from seasonality (Puga et al., 2014) and to focus on changes caused by treatments. The captures were performed at night using mist nets $(3 \times 6 \mathrm{~m})$, which were positioned to intercept bats flying $1-3 \mathrm{~m}$ above the ground. The nets were precisely placed on possible flight routes or exits from shelters.

The experimental procedures were approved by the Ethics Committee of IBILCE-UNESP (Process: 036/2010-CEUA), and the capture of animals was authorized by the Brazilian Institute of the Environment, IBAMA (Process: 21707-1). The animals were treated according to the recommendations of the Committee on Care and Use of Laboratory Animals from the Institute of Laboratory Animal Resources, National Research Council, "Guide for the Care and Use of Laboratory Animals" (Committee on Care and Use of Laboratory Animals, 1980).

\subsection{Castration and maintenance of the animals}

To standardize the study, all animals were castrated in the morning after capture. In castration, the bats were anesthetized with a mixture of ketamine (Dopalen-Vertebrands, Paulínia, SP, Brazil; $370 \mathrm{mg} / \mathrm{kg}$ ) and xylazine (Rompun - Bayer S.A., São Paulo, SP, Brazil; $16 \mathrm{mg} / \mathrm{kg}$ ), which was applied at an amount of $0.1 \mathrm{ml}$ per $50 \mathrm{~g}$ of body weight $(0.08 \mathrm{ml}$ ketamine plus $0.02 \mathrm{ml}$ of xylazine). After anes- 
thesia, bilateral orchiectomy was performed, with a small incision in the inguinal region, in which the testicle and epididymis were removed after cutting the deferent duct.

After castration, the animals were maintained in the Laboratory of Microscopy and Microanalysis of the Department of Biology (IBILCE/UNESP) in a dark room at $25-30^{\circ} \mathrm{C}$. They were accommodated in cages $(100 \times 50 \times 30 \mathrm{~cm}$, length $\mathrm{x}$ width $\mathrm{x}$ height $)$ dotted with grids at the superior portion to facilitate aeration, proper positioning of the animal (upside down) and feeding. Only two or three animals were placed in each cage to avoid the stress of overpopulation. The animals received water ad libitum and, since it is a frugivorous species, they also received fresh and tender fruits (papaya, banana, etc.), which were changed every day. The cages were cleaned every day, with the water exchange and the supplementation of the feed being performed simultaneously in order to cause the lowest possible stress to the animal, with these processes occurring without direct manipulation of the animals. All animals were manipulated only for the performance of the treatments (injections of testosterone).

\subsection{Processing of the animals}

To standardize, all specimens were euthanized in the morning by deep anesthesia (mixture of ketamine and xylazine), administered subcutaneously, and positioned in dorsal decubitus on the dissection board. After the body weight was measured, blood samples were collected by endocardial puncturing. A longitudinal incision in the skin was made, from the anus to the penis, thereby exposing the penile root, allowing the BG to be removed and fixed for analysis.

All specimens were archived in the Chiroptera Collection of the Laboratory of Chiroptera at the Univ. Estadual Paulista, UNESP; Instituto de Biociências, Letras e Ciências Exatas, IBILCE.

\subsection{Serum hormone concentration}

The blood, collected by endocardial puncture, was immediately centrifuged at $1200 \times g$ to separate the serum, and frozen at $-80^{\circ} \mathrm{C}$ for subsequent analysis of testosterone levels. The testosterone concentration were determined by ELISA Capture/Sandwich (antibody-antigen-antibody), using specific commercial kits (Cayman Chemical Company, Ann Arbor, Michigan, USA - Item \# No. $582701)$ of high sensitivity $(6.0 \mathrm{pg} / \mathrm{ml})$, with coefficients of variation for an inter-assay of $32.0 \mathrm{pg} / \mathrm{ml}$. Readings were taken using an Epoch $^{\mathrm{TM}}$ Multi-Volume Spectrophotometer System (BioTekInstruments, VT, USA) reader.

\subsection{Histology}

The BG was fixed by immersion in methyl Carnoyís fixative solution (methanol: chloroform: acetic acid $-6: 3: 1$ ) for $3 \mathrm{~h}$ at $4{ }^{\circ} \mathrm{C}$, dehydrated in ethanol, clarified in xylene and embedded in paraffin (Histosec - MERK, Darmstadt, Germany). Sections of $4 \mu \mathrm{m}$ were stained with hematoxylin-eosin (HE) (Ribeiro and Lima, 2000), periodic acid-Schiff (PAS) (Behmer et al., 1976) and Picrosirius (Junqueira and Carneiro, 2008) or submitted to immunostainings. Microscopic analyses were performed using an Olympus BX60 microscope (Olympus Optical Co., Ltd., Tokyo, Japan) with coupled image analyzer (Image Pro Plus version 6.1 for Windows Copyright $@$ (1993-2006 Media Cybernetics, Inc.).

\subsection{Stereological analysis and morphometry}

The following measurements were performed on cross sections of the BG using the Image Pro-Plus-Media Cybernetics, version 6.1 for Windows software for image analysis: the relative percentage of glandular compartments (epithelium, lumen and stroma), the epithelium height and the cell population census.

Stereology: for this analysis, 50 fields of the slides stained by HE (dorsal region) and Picrosirius (Ventral region) were randomly selected from each experimental group. The relative frequency of glandular components (epithelium, lumen and stroma) was calculated applying an M130 multipoint test system (Weibel, 1963).

Morphometry: to measure the epithelium height, 20 random fields were captured from each animal, with three measurements performed in each field, accumulating a total of 300 measurements for each experimental group.

The cell population census was conducted on blades submitted to P63 immunohistochemistry (protocol described below). For this analysis, 50 fields of the slides submitted to P63 immunohistochemistry were selected from each experimental group. In each field, the amounts of basal and secretory cells were measured by direct counting of nuclei.

\subsection{Transmission electron microscopy}

The BGs were processed for transmission electron microscopy (TEM) as follows. First, the BG was fixed for $24 \mathrm{~h}$ by immersion in a solution of $3 \%$ glutaraldehyde plus $0.25 \%$ tannic acid in Millonig buffer (pH 7.3) containing 0.54\% glucose (Cotta-Pereira et al., 1976). After washing with the same buffer, the samples were post-fixed with $1 \%$ osmium tetroxide for $2 \mathrm{~h}$, dehydrated in a graded series of acetone and embedded in Araldite 502 Resin (Electron Microscopy Sciences, Hatfield, PA, USA). Ultrathin sections $(50 \mathrm{~nm})$ were made using diamond knives, stained with $2 \%$ uranyl acetate for $30 \mathrm{~min}$ (Watson, 1958) followed by $2 \%$ lead citrate in sodium hydroxide for $10 \mathrm{~min}$ (Venable and Coggeshall, 1965) and then analyzed using TEM (906; Leo-Zeiss, Cambridge, UK) at the Center for Microscopy (IBILCE-UNESP).

\subsection{Immunohistochemistry and TUNEL analysis}

For immunohistochemistry analysis, the antigen retrieval was heat-induced in citrate buffer $(10 \mathrm{mM}$ citrate buffer, $\mathrm{pH} 6.0)$ at $98^{\circ} \mathrm{C}$ for $20 \mathrm{~min}$. To block endogenous peroxidase, the slides were treated for 15 min with $10 \%$ hydrogen peroxide in methanol, and nonspecific binding was blocked for $1 \mathrm{~h}$ using 3\% BSA (bovine serum albumin) prior to incubation with primary antibodies against: androgen receptor (AR) - rabbit polyclonal IgG (sc-816/Santa Cruz Biotechnology, Santa Cruz, CA, USA, dilution 1:75 in BSA 1\%, incubated overnight); p63-mouse monoclonal IgG2a (sc-25268/Santa Cruz Biotechnology, Santa Cruz, CA, USA, dilution 1:100 in BSA $1 \%$, incubated for $1 \mathrm{~h}$ ); proliferating cell nuclear antigen (PCNA) mouse monoclonal IgG2a (sc-56/Santa Cruz Biotechnology, Santa Cruz, CA, USA, dilution 1:100 in BSA $1 \%$, incubated for $1 \mathrm{~h}$ ). Sections were then incubated with NovoLink Max Polymer detection system (Leica). For detection of apoptosis, a kit (TUNEL - TdTFragel-Calbiochem, Oncogene Research Products, Boston) was used according to the manufacturer's instructions. The sections were submitted to a reaction with diaminobenzidine (DAB) and counterstained with Harris hematoxylin. Negative controls were used, omitting the incubation step with the primary antibody or enzyme (in the case of TUNEL). To confirm the results, immunostainings were performed in triplicate.

The relative percentage of positive and negative cells in the acinar epithelium was determined using subsequent images of the whole cut length, for which 3 slides per animal were chosen (choosing a slide from the beginning, one from the middle and one from the end). These images were assessed for the number of marked and unmarked nuclei using a System Images Analyzer with Image-Pro Plus 6.0 software. The ratio between the proliferation and cellular apoptosis of the acinar epithelium was also calculated by dividing 

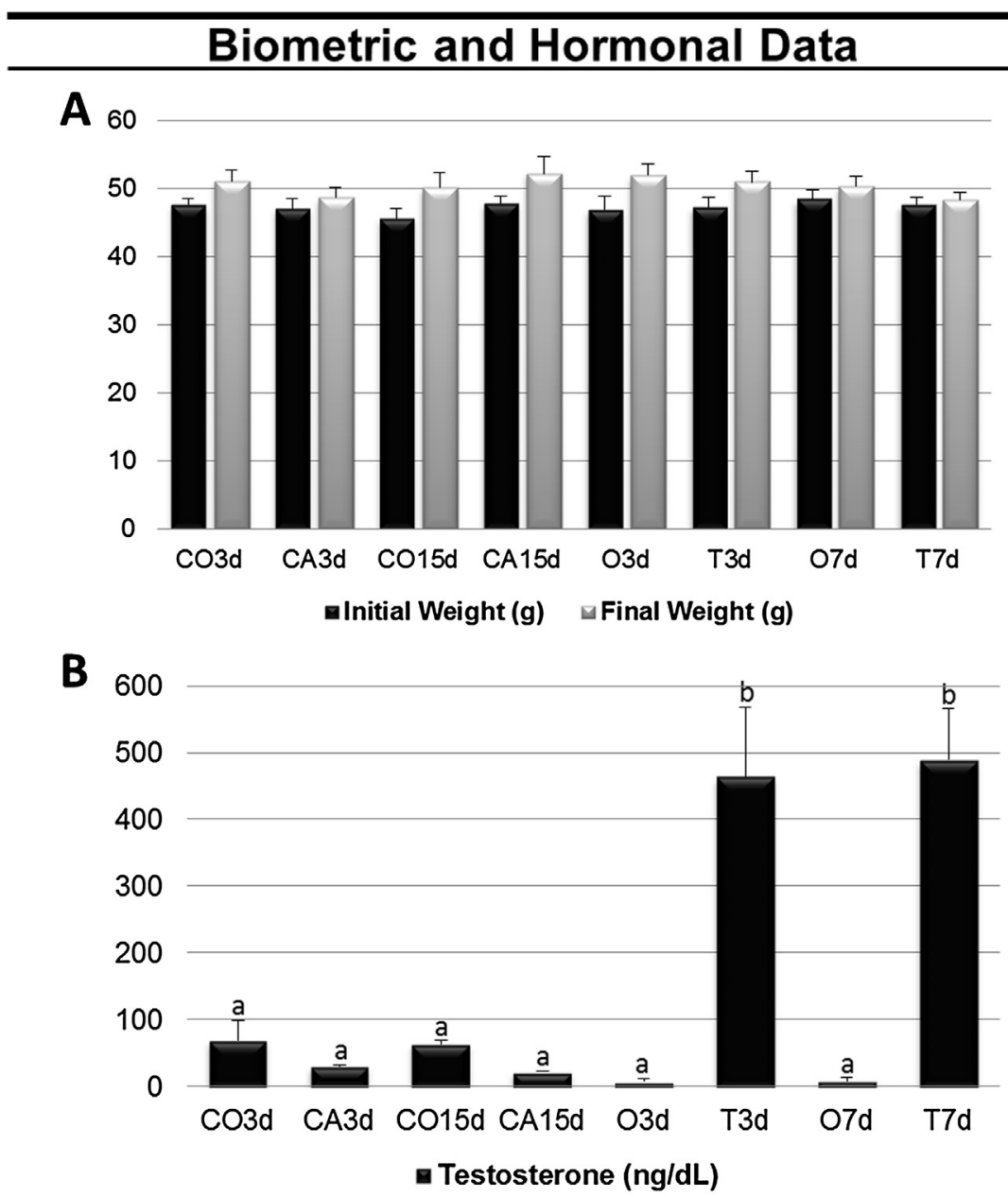

Fig. 2. Biometric and hormonal data.

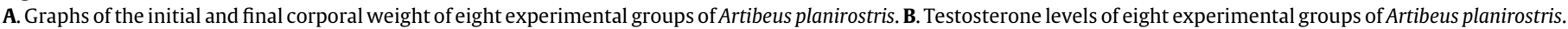
Different superscript letters a,b,c indicate significant differences between groups (Tukeyís test at $\mathrm{p}<0.05$ ).

the percentage of PCNA-positive cells by that of TUNEL-positive cells (\% cell PCNA-positive/\% cell TUNEL-positive).

\subsection{Statistical analysis}

All numerical data were expressed as means and standard error, and analyzed initially by analysis of variance (One-way ANOVA) and, subsequently, by a Tukeyís test for multiple comparisons ( $\mathrm{p} \leq 0.05$ is significant), using the Statistica 7.0 program (Statsoft Inc., Tulsa, USA).

\section{Results}

\subsection{Biometrics and hormonal data}

Although there was an increase in body weight of all animals held in captivity, no significant differences were observed between the initial and final values of body weight (Fig. 2A) in any experimental group. The serum testosterone concentration (Fig. 2B) showed a decrease in the level of testosterone in the CA3d and CA15d groups, when compared with the CO3d and CO15d groups. The O3d and O7d groups showed even lower values (Fig. 2B) and the groups with hormone supplementation had high values (Fig. 2B).

\subsection{Histology, stereological and morphometric analyses}

The BG of the CO3d and CO15d groups showed normal morphology (Fig. 3A, B, E and F), contained a columnar epithelium with basal nuclei, and the secretion is granular and PAS-positive in both lumen and inside the cell. The CA3d group (Fig. 3C and D) had no changes in morphology compared to the controls (Fig. 3A, B, E and F). However, the CA15d group presented a small glandular regression with a reduction of the acini diameter (Fig. $3 G$ and $H$ ). The groups O3d (Fig. 4A and B) and T3d (Fig. 4C and D) showed a similar morphology to the CA15d group (Fig. 3 C and D), presenting a small glandular regression.

Long-term treatment without testosterone (O7d) showed a great glandular regression (Fig. $4 \mathrm{E}$ and $\mathrm{F}$ ), with a change in the pattern of glandular secretion, and an increase in stromal areas. However, the long-term treatment with testosterone (T7d) showed a return to normal glandular morphology, with a decline in stromal areas (Figs. $4 \mathrm{G}$ and $\mathrm{H}$ ).

Stereologically, the BG showed no significant changes in groups CO3d, CA3d, CO15d or CA15d. However, there was a tendency for a small reduction in the epithelium and increased stroma in the CA15d group (Fig. 5A). In the supplementation of testosterone, the epithelium decreased significantly in the 07d group, while the lumen increased in groups treated with testosterone (T3d and T7d) and stroma decreased in T7d (Fig. 5B). 


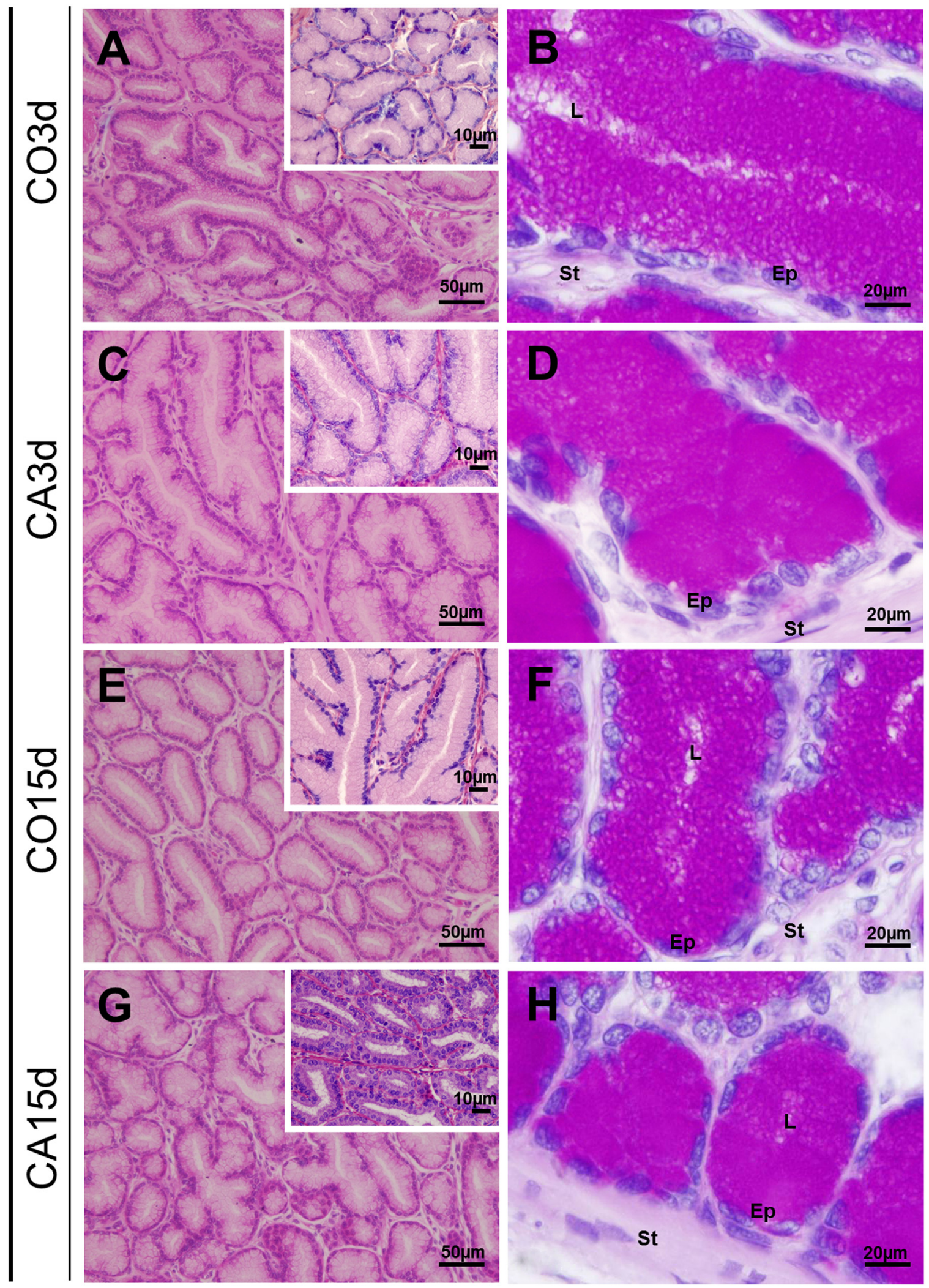

Fig. 3. Histological general pattern of the bulbourethral gland of four experimental groups of Artibeus planirostris.

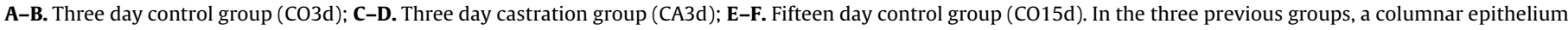

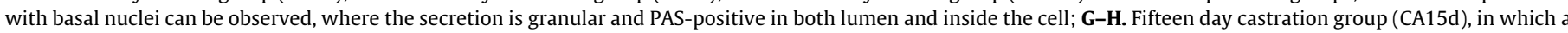

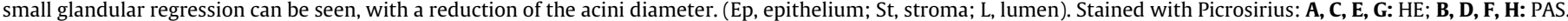



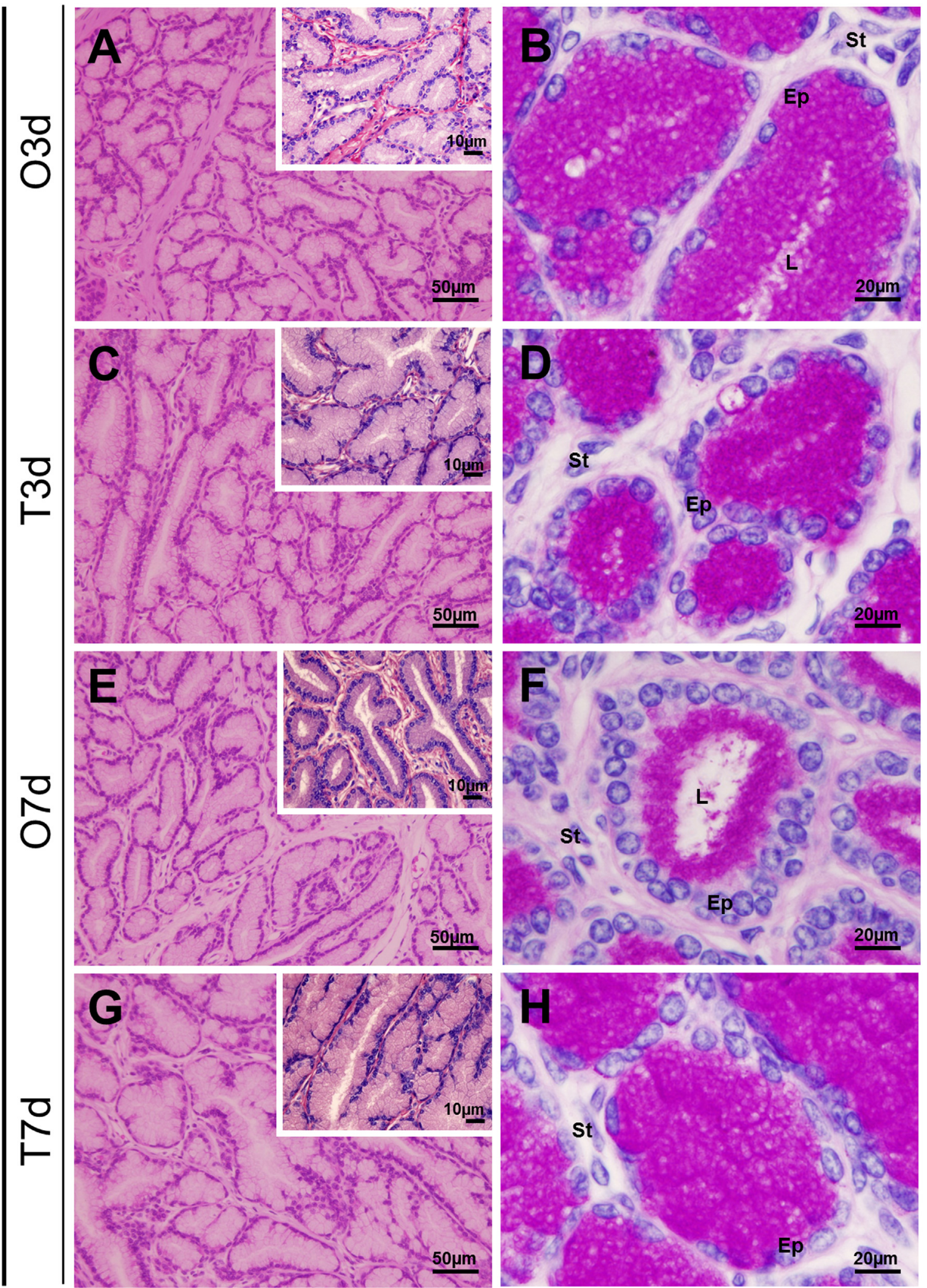

Fig. 4. Histological general pattern of the bulbourethral gland of four experimental groups of Artibeus planirostris.

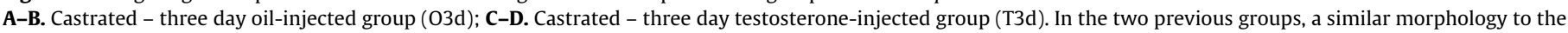

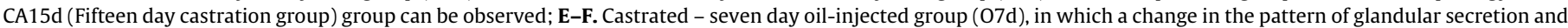

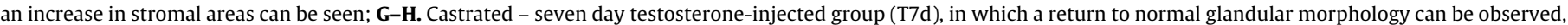
with a decline in stromal areas. (Ep, epithelium; St, stroma; L, lumen). Stained with Picrosirius: A, C, E, G: HE; B, D, F, H: PAS. 

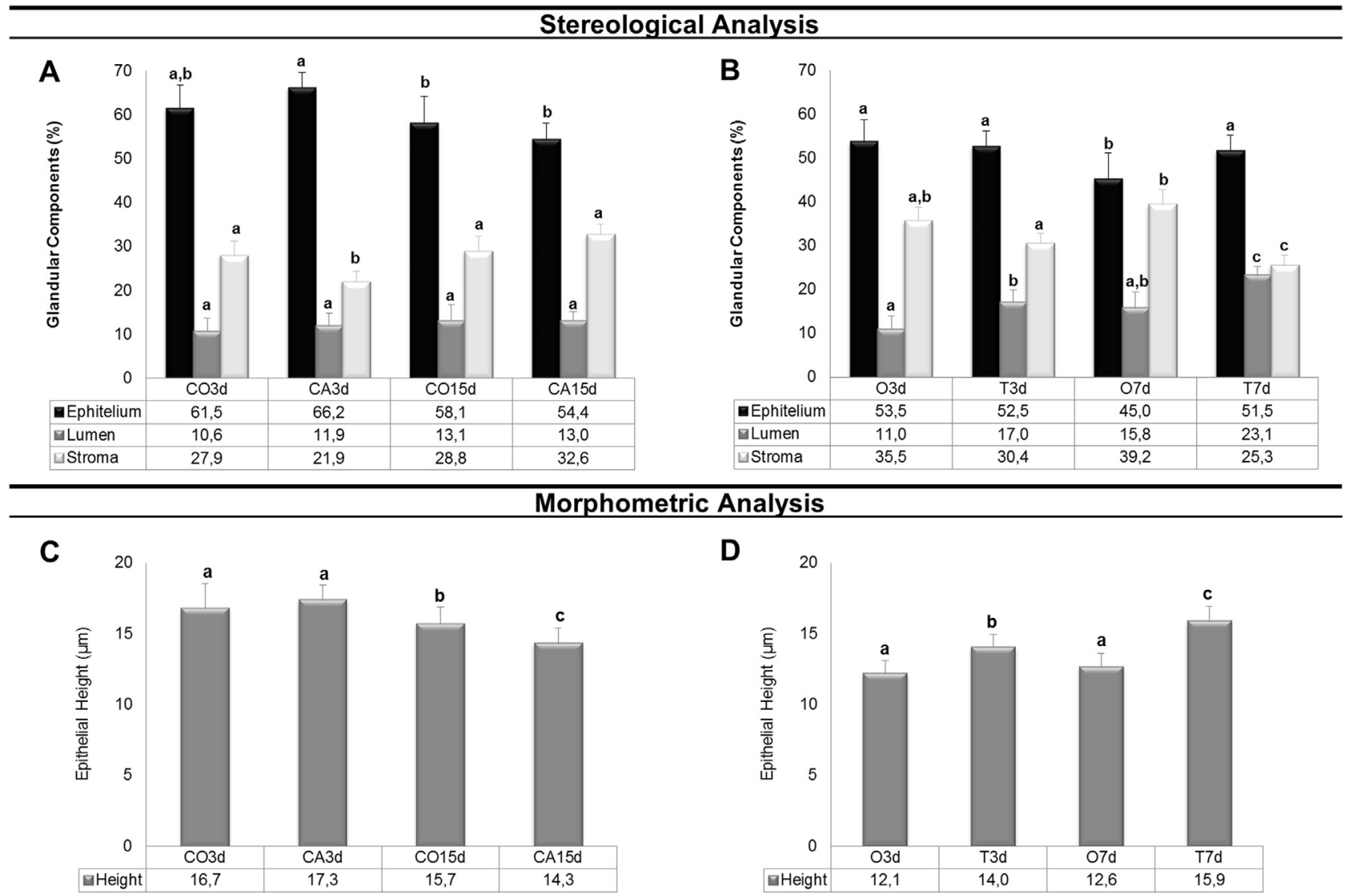

D

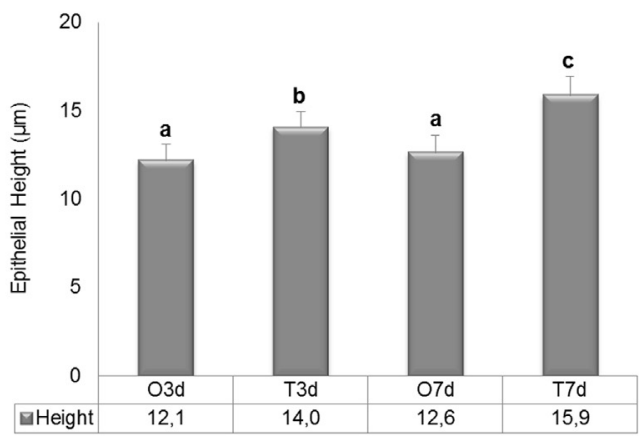

Fig. 5. Stereology (A and B) and morphometry (C and D) of the bulbourethral gland of the eight experimental groups of Artibeus planirostris:.

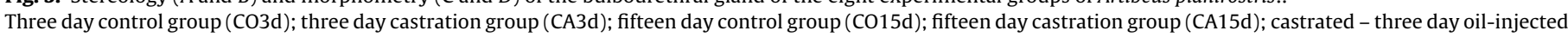

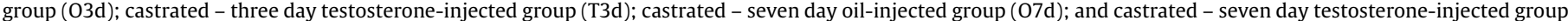

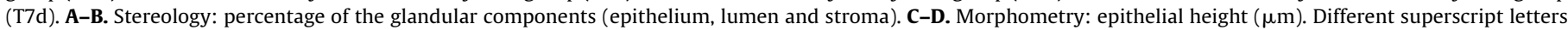
a,b,c indicate significant differences between groups (Tukeyís test at $\mathrm{p}<0.05$ ).

For morphometry, there was a small decline in the epithelium height in the CA15d group (Fig. 5C); similarly, oil-treated groups (O3d and O7d) showed a decrease in epithelium height. The groups treated with testosterone (T3d and T7d; Fig. 5D) showed an increase in the epithelium height, which was more pronounced in the group treated with testosterone for a longer time (T7d).

\subsection{Ultrastructural data}

The BG did not present differences in ultrastructure in the groups CO3d, CA3d, CO15d or CA15d (Fig. 6). The BG had a columnar epithelium, with basal nuclei (Fig. 6A, D, G and J), and these were filled with many secretion droplets of variable electron density (Fig. 6). These vesicles were released at the apex of the epithelium, where small projections of the cell membrane are found (Fig. 6C, $\mathrm{F}$ and $\mathrm{L}$ and detail in Fig. 6I). In all groups, the cells presented a cytoplasm with a large volume of endoplasmic reticulum and Golgi complexes (Fig. 6B, E, $\mathrm{H}$ and $\mathrm{K}$ ).

The groups O3d (Fig. 7A-C) and T3d (Fig. 7D-F) showed an ultrastructure similar to the groups already described. Moreover, the O7d group (Fig. 7G-I) showed a decrease in secretory vesicles, which were concentrated at the apex of the cell, and of cellular components, such as endoplasmic reticulum and Golgi complex. Finally, the group treated with testosterone for seven days (T7d) showed a return of glandular activity, with many secretory vesicles, and with a large volume of endoplasmic reticulum and Golgi complexes (Fig. 7J-L)

\subsection{Cell population census}

The cell population census revealed a significant increase in the number of basal and other cells in the CA15d group (Fig. 8A and D), in relation to the CO3d, CA3d and CO15d groups (Fig. 8A and C). In the groups treated with testosterone for a long period (T7d), there was a decrease in the number of other cells in relation to the O3d, T3d and O7d groups (Fig. 8B, E), but the basal cells remained constant (Fig. 8B, E and F).

\subsection{Index of p63-positive cell/p63-negative cell}

Dividing the number of basal cells by the other cells enabled the development of an index, which indicated that the BG did not show significant changes in the CO3d, CA3d, CO15d and CA15d groups. However, there was a tendency for an increase in the index in the CA15d group (Table in Fig. 8). In the supplementation of testosterone, it can be observed that the O3d group showed a decline in the index, and that the T7d group showed a return to the initial index (Table in Fig. 8).

\subsection{Immunohistochemistry}

\subsubsection{Androgen receptor (AR)}

The AR immunohistochemistry showed an increase in ARpositive cells in the CO15d group in relation to the CO3d, CA3d and Ca15d groups (Fig. 9A, C and D). On the other hand, in the hormone supplementation groups, there was a significant increase in AR-positive cells in the groups treated with testosterone (T3d 


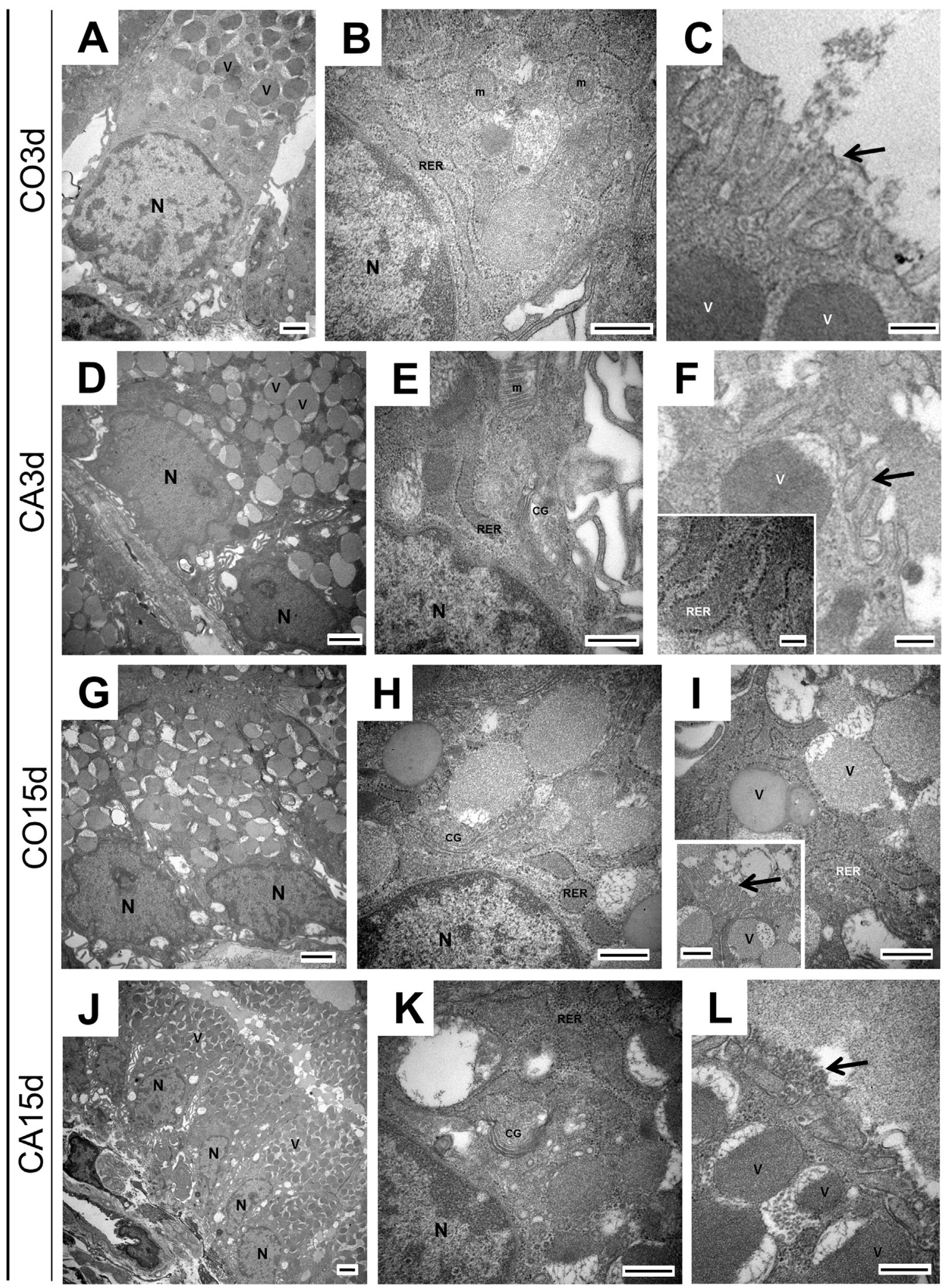

Fig. 6. Ultrastructural data of the bulbourethral gland of four experimental groups of Artibeus planirostris.

A-C. Three day control group (CO3d); D-F. Three day castration group (CA3d); G-I. Fifteen day control group (CO15d); J-L. Fifteen day castration group (CA15d). Note the nuclei basal and the vesicle secretion in the apex $(\mathbf{A}, \mathbf{D}, \mathbf{G}, \mathbf{J})$ and the large amount of endoplasmic reticulum in the cellular cytoplasm $(\mathbf{B}, \mathbf{E}, \mathbf{H}, \mathbf{I}, \mathbf{K}$ and detail of $\mathbf{F})$, in $\mathbf{C}, \mathbf{F}$, $\mathbf{L}$ and detail of I, note the apex of the cell with secretory surface (arrows). (CG, Golgi complex; m, mitochrondria; N, nucleus; RER, endoplasmic reticulum; V, vesicle). Scale bar: $2000 \mathrm{~nm}(\mathbf{D}, \mathbf{G}, \mathbf{J}) ; 1000 \mathrm{~nm}$ (A, B, E, H, I, K, L); $250 \mathrm{~nm}$ (C, F). 

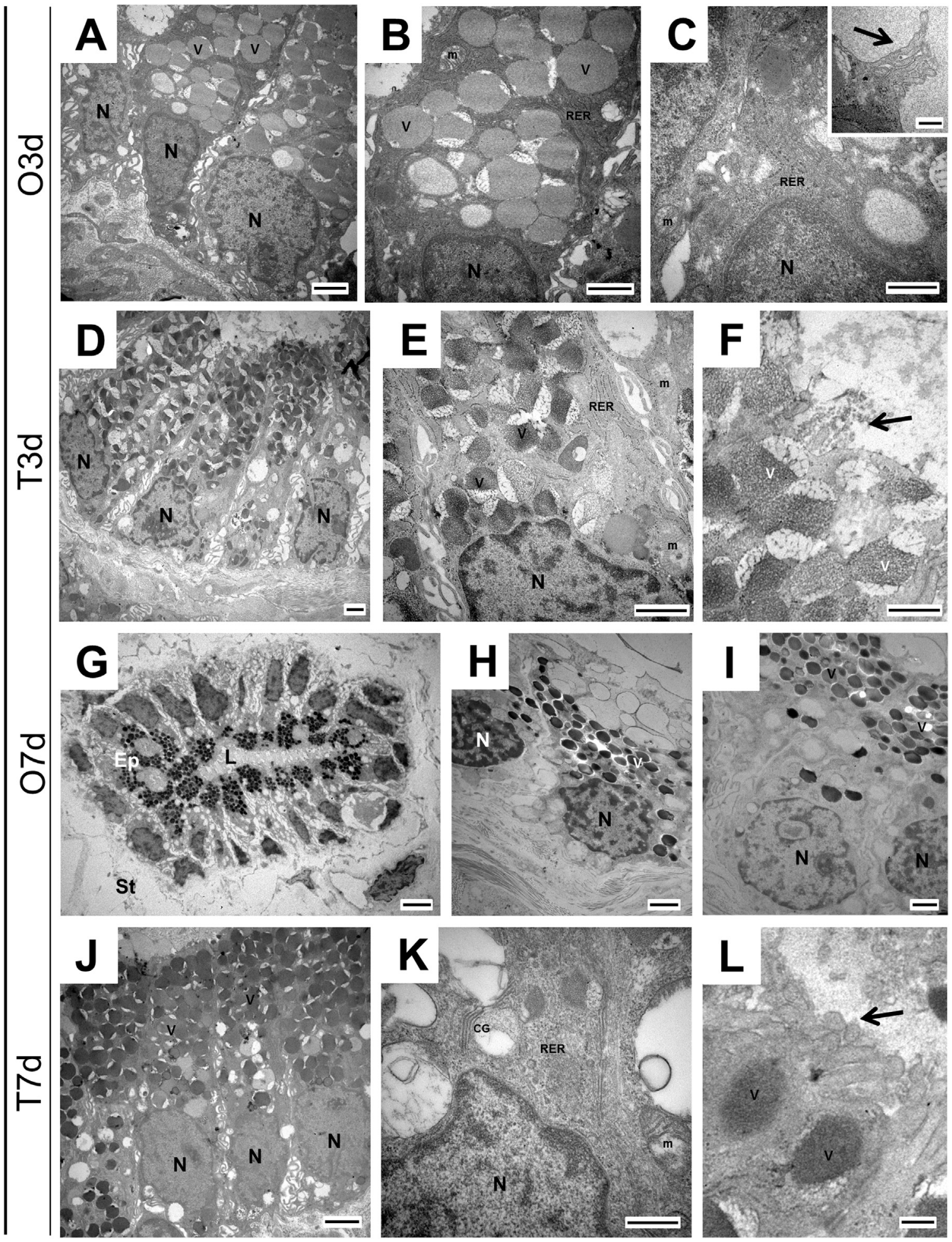

Fig. 7. Ultrastructural data of the bulbourethral gland of four experimental groups of Artibeus planirostris.

A-C. Castrated - three day oil-injected group (03d). D-F. Castrated - three day testosterone-injected group (T3d). Note that both groups are similar to the groups already described. G-I. Castrated - seven day oil-injected group (07d), note the decreased secretory vesicles, which were concentrated at the apex cell and of cellular components. J-L. Castrated - seven day testosterone-injected group (T7d), note the return of gland activity, with many secretory vesicles with large volume of endoplasmic reticulum and Golgi complex apparent. (Arrow, Apex secretion; Ep, epithelium; CG, Golgi complex; L, lumen; m, mitochondria; N, nucleus; RER, endoplasmic reticulum; St, stroma; V, vesicle). Scale bar: $5 \mu \mathrm{m}(\mathbf{G}) ; 4000 \mathrm{~nm}(\mathbf{J}) ; 2000 \mathrm{~nm}(\mathbf{A}, \mathbf{B}, \mathbf{D}, \mathbf{F}, \mathbf{H}, \mathbf{I}) ; 1000 \mathrm{~nm}(\mathbf{C}, \mathbf{K}) ; 500 \mathrm{~nm}$ (detail of C, L). 


\section{Cell Population Census}

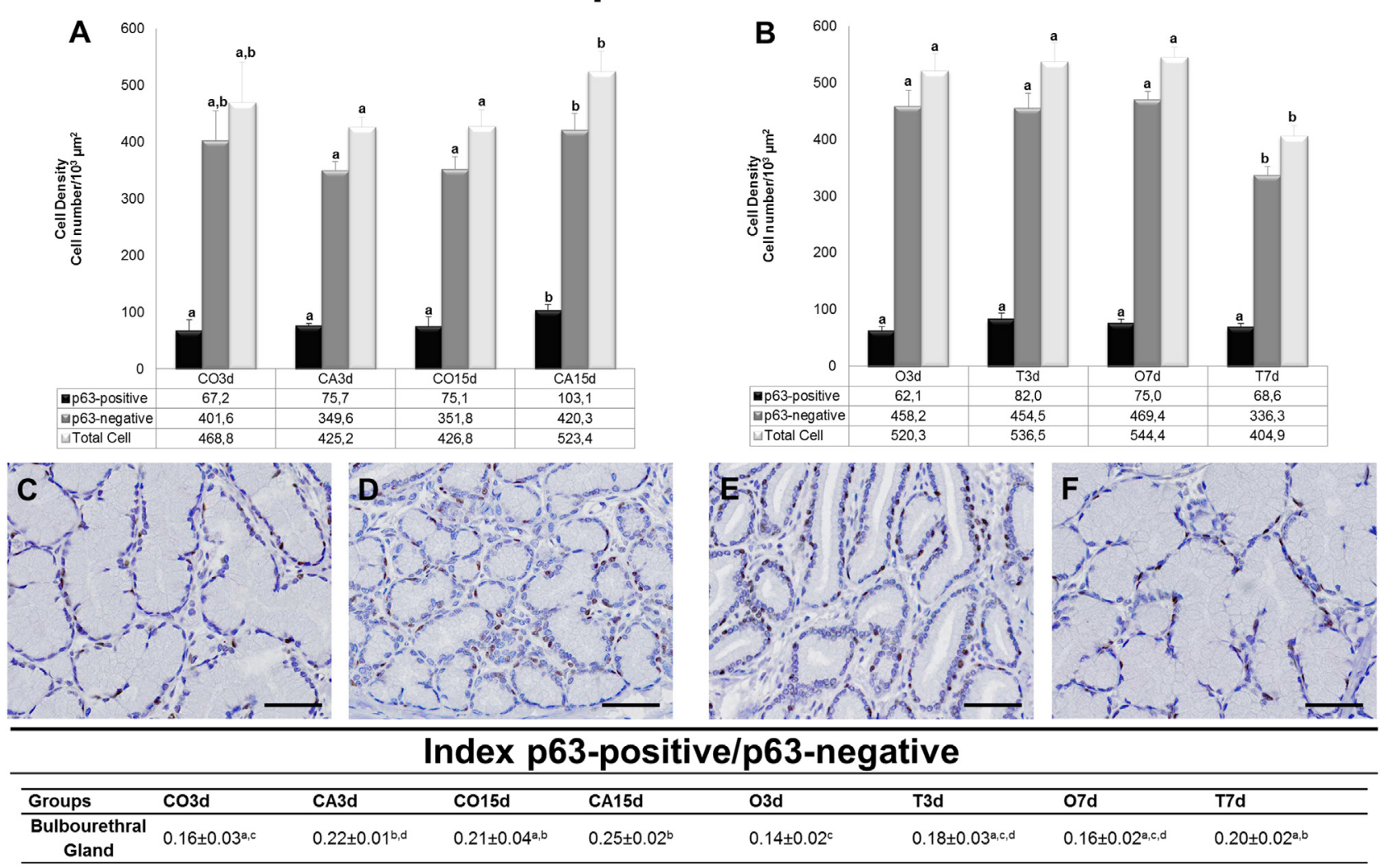

Fig. 8. Cell population census analyses of the bulbourethral gland of Artibeus planirostris submitted to p63 immunohistochemistry.

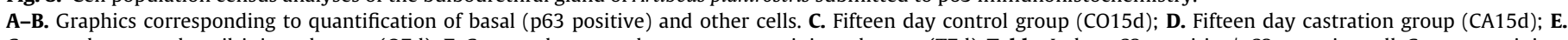

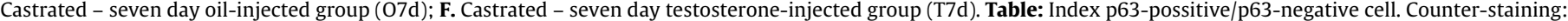
Hematoxylin. Different superscript letters $\mathrm{a}, \mathrm{b}, \mathrm{c}$ indicate significant differences between groups (Tukeyís test at $\mathrm{p}<0.05$ ). Scale bar: $50 \mu \mathrm{m}$.

and T7d), and a decrease in the castrated groups not treated with testosterone (O3d and O7d) (Fig. 9B, E and F).

\subsubsection{Cell proliferation (PCNA)}

PCNA did not show significant differences in the castrated groups (CO3d, CA3d, CO15d and CA15d, Fig. 10A, C and D). The O3d and 07d groups showed a decrease in PCNA-positive cells in comparison with the CA3d and CA15d groups (Fig. 10A-E). The groups submitted to hormone supplementation for three and seven days [T3d (Fig. 10B, E and H) and T7d] had an increase in proliferation.

\subsubsection{Apoptosis (TUNEL)}

The BG showed a significant increase in the number of apoptotic cells only in the $07 \mathrm{~d}$ group (Fig. 10H). In the other groups, the values did not differ significantly.

\subsubsection{Rate of cell proliferation (PCNA/TUNEL)}

The PCNA/TUNEL ratio showed an increase in the CA15d group compared to control groups (CO3d, CA3d and CO15d) and there was a decline in the castrated group given no long-term testosterone (O7d).

\section{Discussion}

This study represents the first evaluation of the relationship between testosterone and the BG in bats. The BG is a gland important in the reproductive system of mammals. Its secretion is released before ejaculation, and its function is to clear the urethra and help vaginal lubrication (Samuelson, 2007).

There are few studies related to the effect of castration on BG, with these showing different responses among mammals (Aykroyd and Zuckerman, 1938; Heller, 1932). The literature related to the influence of androgens in the reproductive glands is always related to the prostate gland. Thus, based on the importance of this gland, in the absence of work related to the subject, a conflicted relationship of the BG with testosterone in mammals and the wide variation in reproductive patterns of bats, this study emphasizes the importance of evaluating the effect of testosterone in the BG of A. planirostris, through castration and posterior hormone supplementation.

Though in this study no significant differences were observed between the initial and final values of body parameters in any experimental groups, there was an increased body weight of all animals held in captivity. This shows that castration and subsequent hormone supplementation did not significantly influence the weight of the animals.

The testosterone concentration showed a tendency to decrease in the CA3d and CA15d groups, when compared with the CO3d and CO15d groups, but the BG presented only a small regression in the CA15d group. Only in the O7d group was there a great glandular regression, indicating that the $\mathrm{BG}$ of $A$. planirostris is less dependent on testosterone than the prostate, as its regression occurred after 22 days, whereas it occurred in the prostate 15 days after castration (Puga et al., 2016). In other mammals, this late response is also found; for example, in rhesus monkeys, there was regression only in 


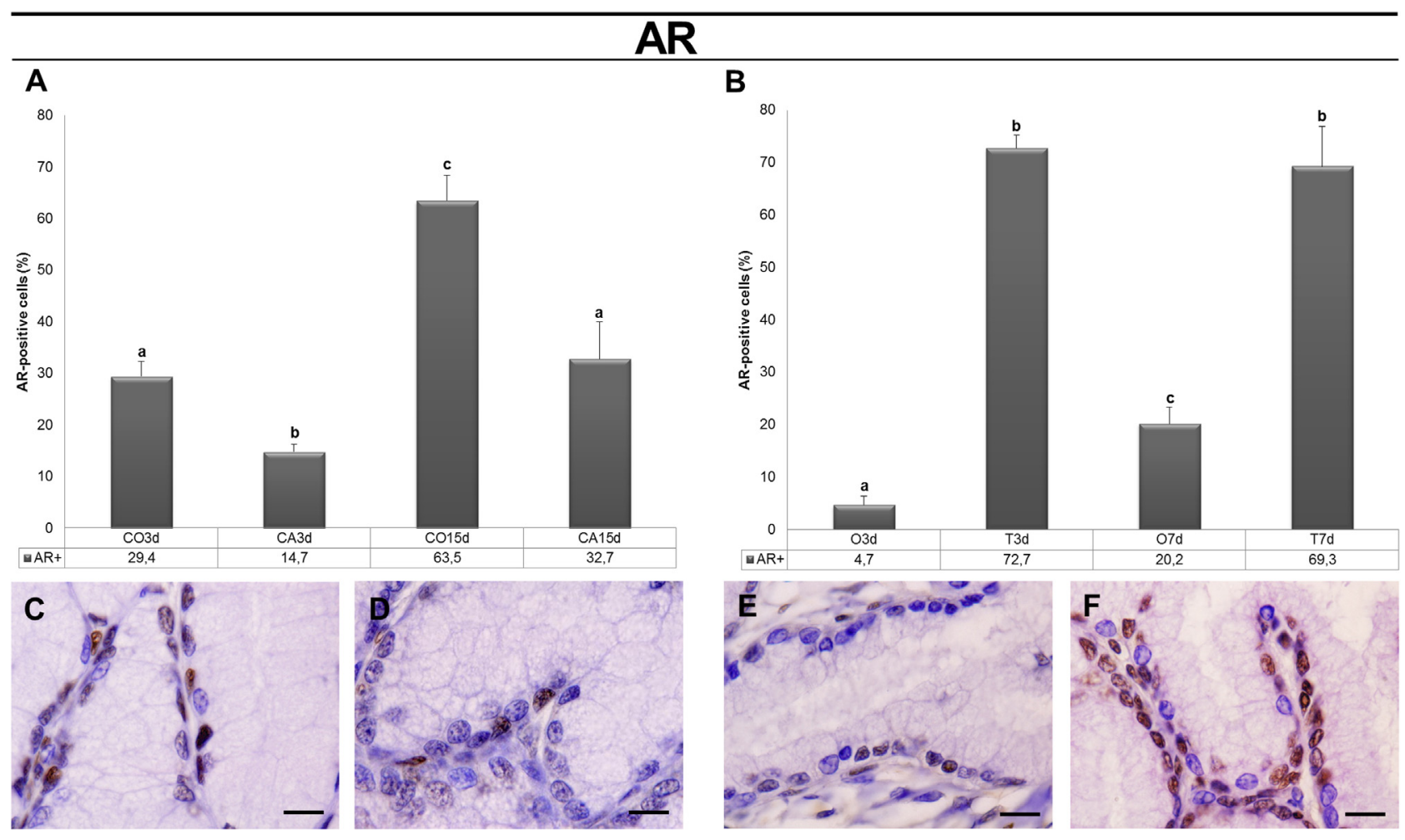

Fig. 9. Immunostaining of the androgen receptor (AR) in all experimental groups of bulbourethral gland of Artibeus planirostris.

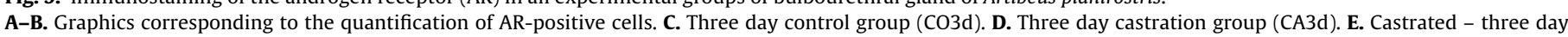

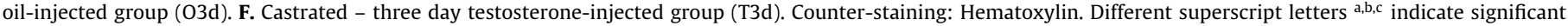
differences between groups (Tukeyís test at $\mathrm{p}<0.05$ ). Scale bar: $10 \mu \mathrm{m}$.

the peripheral part of the BG five months after castration (Aykroyd and Zuckerman, 1938), and in guinea pigs, little regression occurred in the first year after castration (Barrington, 1913, apud Aykroyd and Zuckerman, 1938) in guinea pigs. Only in the BG of the rats are these results different; in this case, quick and marked changes post-castration are shown.

The long-term treatment with testosterone (T7d) showed a return to normal glandular morphology, with a decline in stromal areas, thus showing that there is a rapid return of the gland when the animal is injected with testosterone. This response suggests that BG is influenced by testosterone, but only with drastic changes in testosterone levels, such as castration and supplementation with supraphysiological concentrations, as found for treatments used in other studies (Baltaci et al., 2006; Aykroyd and Zuckerman, 1938). The ultrastructure confirmed the regression of the bulbourethral gland in castrated groups for 22 days, and showed a change in the pattern of secretion, in the castrated group for 22 days presents more electrodense droplet.

The cell population census indicated an increase in the number of basal and other cells in the CA15d group; however, this increase is closely associated with the initial glandular regression itself, as there was an accentuated decrease in the acini and decrease of epithelial height.

The androgen receptor showed little staining of epithelial cells in the control groups. This may be related to a delay in response of this gland to testosterone. When the testosterone level decreases, the number of AR-positive cells also decreases, causing the glandular regression confirmed in morphology. Cordeiro et al. (2008) observed that, in prostate, AR expression was directly related to levels of serum testosterone, decreasing in castrated animals and increasing in animals treated with testosterone, which is according to the present results observed in the BG.
The cell proliferative and apoptotic rate was significantly different only in the long-term castrated group (07d), showing that the BG has a smaller dependency to the lack of testosterone than other male reproductive glands. The prostate, for example, presents a significant regression in animals castrated after at least 15 days (Puga et al., 2016).

There are few studies related to the effect of castration on the BG, with these showing different responses among mammals. In these studies, the effect of castration was observed over long periods. Aykroyd and Zuckerman (1938) showed that there was regression only in the peripheral part of the BGs of mature male rhesus monkeys that had been castrated for five months and Barrington (1913), apud Aykroyd and Zuckerman (1938) noticed little regression in the first year after castration in guinea pigs. These results are very different from those found for rats (Heller, 1932), which show quick and marked changes post-castration.

In conclusion, the present study provides the first information on the histological and ultrastructural features of the BG in the bat (Artibeus planirostris) subjected to castration and hormone supplementation. The study showed that the BG takes longer to respond to ablation of testosterone than other reproductive glands, as regression was only observed in the group 22 days after castration (O7d). Testosterone itself has a high intra-diurnal variation. Further studies could be aimed at lower concentration of externally administered testosterone for a longer period.

\section{Funding}

This work was supported by the São Paulo State Research Foundation - FAPESP [2011/01323-2 to C.C.I.P.; 2012/09194-0 to M.R.B.]; and the Brazilian National Research and Development Council (CNPq) [300163/2008-8 and 301596/2011-5 to SRT. 


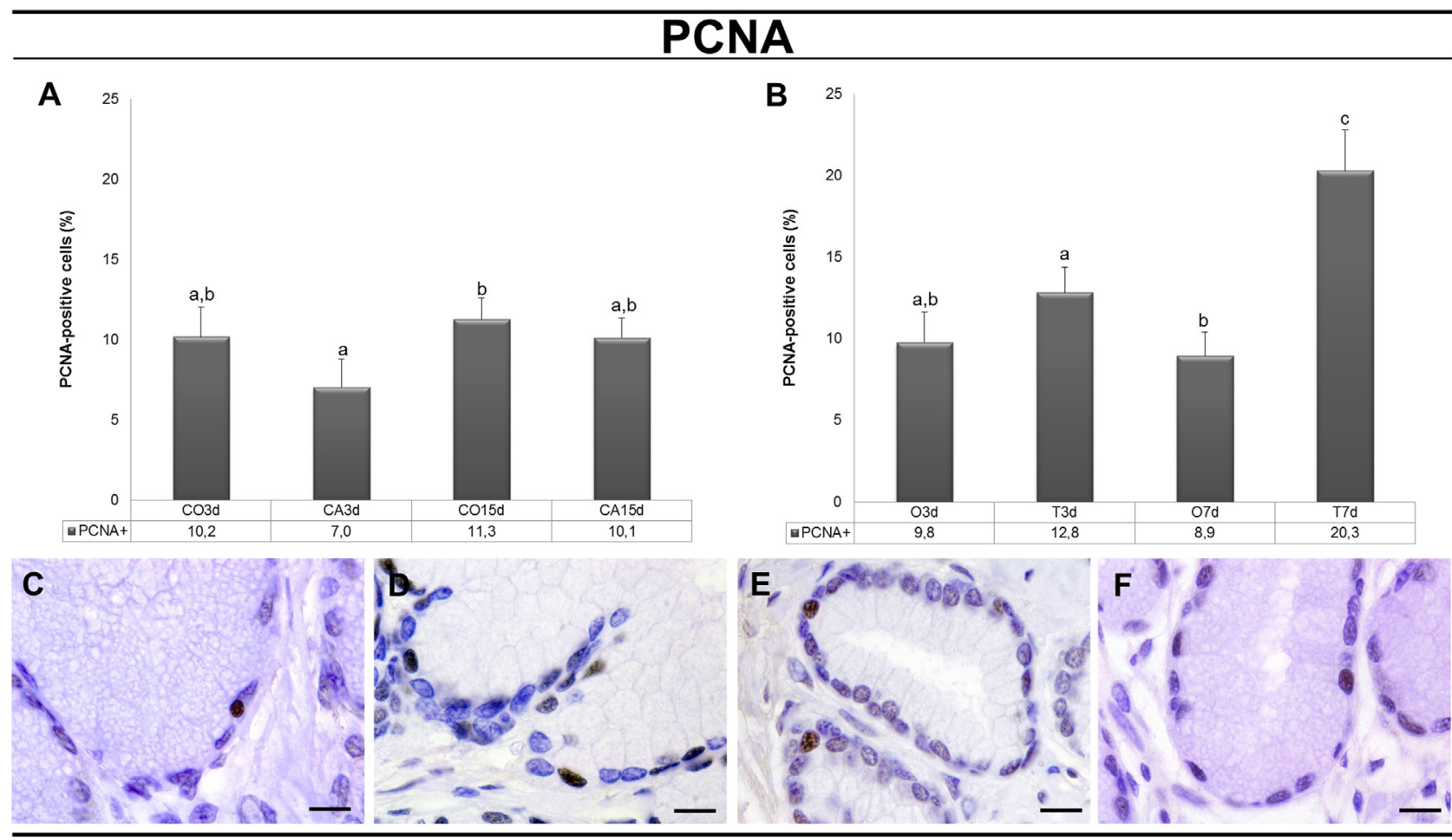

TUNEL

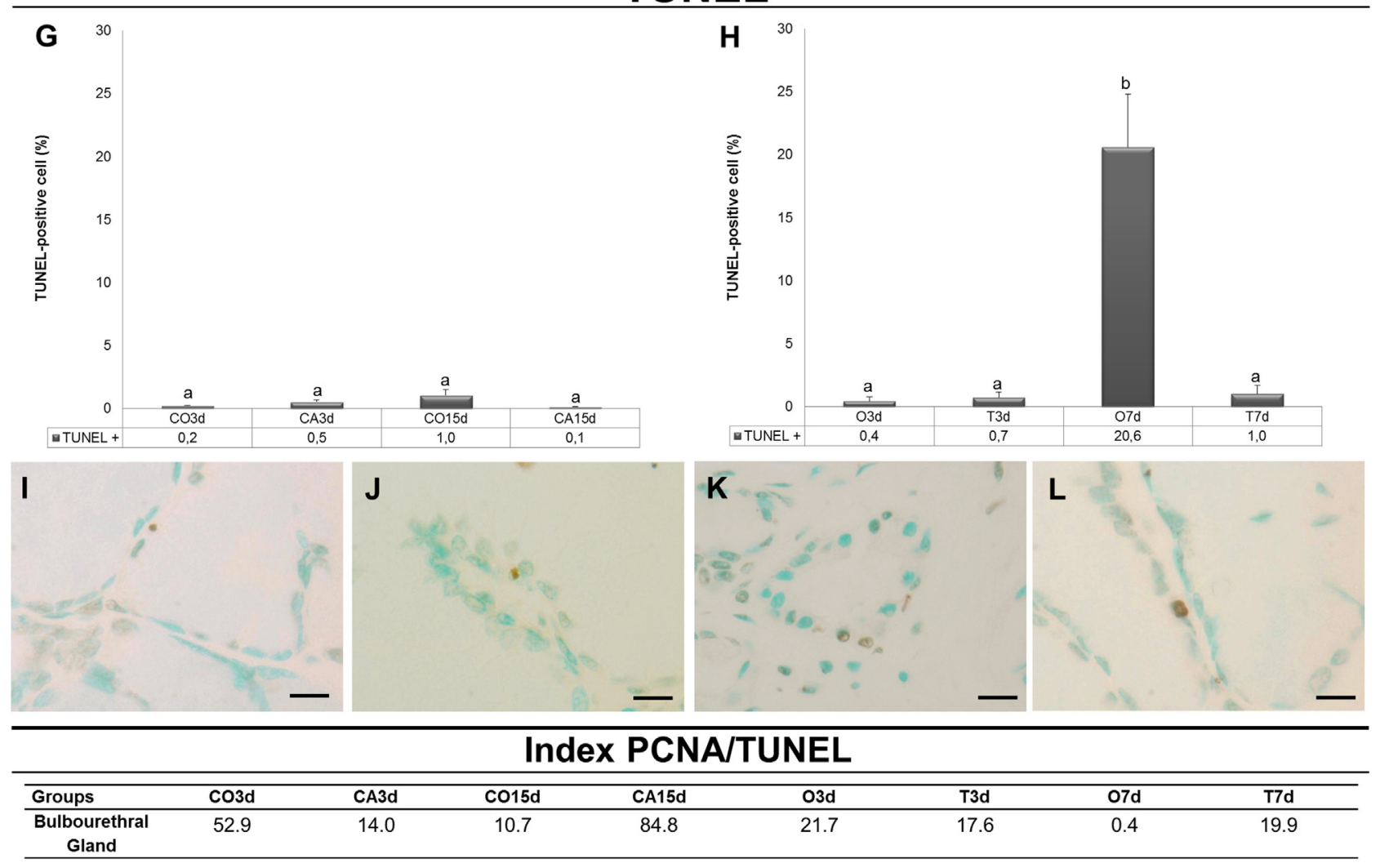

Fig. 10. Amount of proliferation (PCNA) and apoptotic cell (TUNEL) in all experimental groups of bulbourethral gland of Artibeus planirostris.

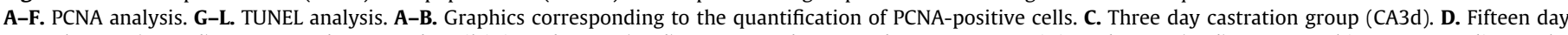

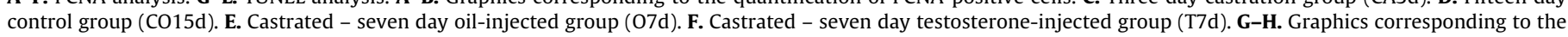

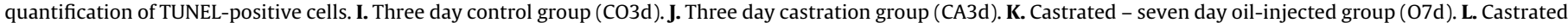

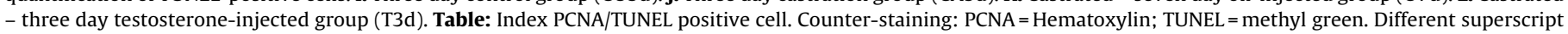
letters ${ }^{a, b, c}$ indicate significant differences between groups (Tukeyís test at $\mathrm{p}<0.05$ ). Scale bar: $10 \mu \mathrm{m}$. 


\section{Acknowledgements}

We thank Luiz Roberto Falleiros Junior and Rosana Silistino de Souza for technical help.

\section{References}

Adaro, L., Mendoza, A., Cepeda, R., Orostegui, C., 2001. Anatomo-radiographic study of the seminal vesicles of chinchilla (Chinchilla laniger) in captivity. Rev. Chil. Anat. 19, 297-300.

Adebayo, A.O., Akinloye, A.K., Olukole, S.G., Oyeyemi, M.O., Taiwo, V.O., Ihunwo, A.O., Oke, B.O., 2015. Gross, histological and ultrastructural features of the bulbourethral gland in the greater cane rat (Thryonomys swinderianus). Anat. Histol. Embryol. 44 (1), 59-65.

Aykroyd, O.E., Zuckerman, S., 1938. The effect of sex-hormones on the bulbourethral glands of rhesus monkeys. J. Anat. Oct. 73 (1), 135-144.

Badia, E., Briz, M.D., Pinart, E., Sancho, S., Garcia, N., Bassols, J., Pruenda, A., Brusasalleu, E., Yeste, M., Casas, I., Bonet, S., 2006. Structural and ultrastructural features of boar bulbourethral glands. Tissue Cell 38, 7-18.

Baltaci, A.K., Mogulkoc, R., Ozturk, A., 2006. Testosterone and zinc supplementation in castrated rats: effects on plasma leptin levels and relation with LH, FSH and testosterone. Life Sci. 78, 746-752.

Beguelini, M.R., Taboga, S.R., Morielle-Versute, E., 2012. Análise Ultraestrutural E Imunocitoquímica Da Espermatogênese E Nucleologênese De Morcegos. 222f. Tese (Doutorado Em Genética). Instituto de Biociências, Letras e Ciências Exatas, UNESP, São José do Rio Preto.

Beguelini, M.R., Puga, C.C.I., Martins, F.F., Betoli, A.H., Taboga, S.R., Morielle-Versute, E., 2013a. Morphological variation of primary reproductive structures in males of five families of neotropical bats. Anat. Rec. (Hoboken) 296 (1), 156-167.

Beguelini, M.R., Puga, C.C.I., Taboga, S.R., Morielle-Versute, E., 2013b. Annual reproductive cycle of males of the flat-faced fruit-eating bat, Artibeus planirostris (Chiroptera: phyllostomidae). Gen. Comp. Endocrinol. 185, 80-89.

Beguelini, M.R., Bueno, L.M., Caun, D.L., Taboga, S.R., Morielle-Versute, E., 2014a. Ultrastructure of spermatogenesis in the short-tailed fruit bat, Carollia perspicillata (Chiroptera: phyllostomidae: Carollinae). J. Morphol. 275 (1), $111-123$.

Beguelini, M.R., Falleiros Jr, L.R., Góes, R.M., Rahal, P., Morielle-Versute, E., Taboga, S.R., 2014b. Differential expression of aromatase, estrogen receptor alpha and $17 \beta-H S D$ associated with the processes of total testicular regression and recrudescence in the bat Myotis nigricans (Chiroptera: vespertilionidae). Gen. Comp. Endocrinol. 201, 53-64.

Behmer, O.A., Tolosa, E.M.C., Freitas-Neto, A.G., 1976. Manual de Técnicas Para Histologia Normal E Patológica. EDART Editora da Universidade de São Paulo, São Paulo.

Cakir, M., Karatas, A., 2004. Histo-anatomical studies on the accessory reproductive glands of the anatolian souslik (Spermophilus xanthoprymnus) (Mammalia: sciuridae). Anat. Histol. Embryol. 33, 146-150.

Christante, C.M., Beguelini, M.R., Puga, C.C.I., Negrin, A.C., Morielle-Versute, E., Vilamaior, P.S.L., Taboga, S.R., 2015. Structure, histochemistry and seasonal variations of the male reproductive accessory glands in the Pallas's mastiff bat, Molossus molossus (Chiroptera: molossidae). Reprod. Fertil. Develop. 27 (2), 313-322.

Cordeiro, R.S., Scarano, W.R., Campos, S.G.P., Santos, F.C.A., Vilamaior, P.S.L., Goes, R.M., Taboga, S.R., 2008. Androgen receptor in the Mongolian gerbil ventral prostate: evaluation during different phases of postnatal development and following androgen blockage. Micron 39, 1312-1324.

Cotta-Pereira, G., Rodrigo, F.G., David-Ferreira, J.F., 1976. The use of tannic acid-glutaraldehyde in the study of elastic related fibers. Stain. Technol. 51, 7-11.

Dyce, K.M., Sack, W.O., Wensing, C.J.G., 2002. Text Book of Veterinary Anatomy, 3rd edn. Saunders, Philadelphia, PA.

Heller, R.E., 1932. Cowper's gland and its reaction to castration and to different sex hormone conditions. Am. J. Anat. 50, 73-95.

Jequier, A.M., 1995. Clinical disorders affecting semen quality. In: Yovich, J.L. (Ed.), Gametes-The Spermatozoon. University Press, Cambridge, pp. 175-191.
Jesik, C., Holland, J., Lee, C., 1982. An anatomic and histologic study of the rat prostate. Prostate 3, 81-97.

Jolly, S.E., Blackshaw, A.W., 1987. Prolonged epididymal sperm storage and the temporal dissociation of testicular and accessory gland activity in the common sheath tailed bat, Taphozous georginanus of tropical Australia. J. Reprod. Fertil. $81,205-211$.

Junqueira, L.C.U., Carneiro, J., 2008. Histologia Básica. Guanabara Koogan, Rio de Janeiro.

Knegt, L.V., Silva, J.A., Moreira, E.C., Sales, G.L., 2005. Bats found in the city of Belo Horizonte, MG, 1999-2003. Arq. Bras. Med. Vet. Zootec. 57, 576-583.

Kyprianou, N., Issacs, J.T., 1988. Activation of programmed cell death in the rat ventral prostate after castration. Endocrinology 122, 552-562.

Martins, F.F., Puga, C.C., Beguelini, M.R., Morielle-Versute, E., Vilamaior, P.S., Taboga, S.R., 2015. Comparative analysis of the male reproductive accessory glands of bat species from the five Brazilian subfamilies of the family Phyllostomidae (Chiroptera). J. Morphol. 276 (4), 470-480.

Puga, C.C.I., Beguelini, M.R., Negrin, A.C., Christante, C.M., Morielle-Versute, E., Vilamaior, P.S.L., Taboga, S.R., 2013. Structure, histochemistry and ultrastructure of the male reproductive accessory glands in the neotropical flat-faced fruit-eating bat, Artibeus planirostris (Chiroptera: phyllostomidae). Reprod. Fertil. Dev. 25, 558-569.

Puga, C.C.I., Beguelini, M.R., Martins, F.F., Morielle-Versute, E., Faleiros-Jr, L.R., Vilamaior, P.S.L., Taboga, S.R., 2014. Seasonal changes in the prostatic complex of Artibeus planirostris (Chiroptera: phyllostomidae). Gen. Comp. Endocrinol. 197, 33-42.

Puga, C.C.I., Beguelini, M.R., Morielle-Versute, E., Vilamaior, P.S.L., Taboga, S.R., 2016. The effects of testosterone in prostatic complex of Artibeus planirostris (Chiroptera: phyllostomidae). Tissue Cell, http://dx.doi.org/10.1016/j.tice. 2016.02.006.

Puga, C.C.I., 2011. Morfofisiologia Das Glândulas Reprodutivas Acessórias Masculinas De Morcegos: Estudo Nas Espécies Artibeus Planirostris E Platyrrhinus Lineatus (Chiroptera: Phyllostomidae). Dissertação (Mestrado). Universidade Estadual Paulista, Instituto de Biociências, Letras e Ciências Exatas, São José do Rio Preto.

Racey, P.A., 1978. Seasonal changes in testosterone levels and androgen dependent organs in male moles (Talpa europaea). J. Reprod. fertil. 52, 195-200.

Ribeiro, M.G., Lima, S.R., 2000. Iniciação às técnicas De Preparação De Material Para O Estudo E Pesquisa Em Morfologia. SEGRAC-Editora e Gráfica Limitada, Belo Horizonte.

Risbridger, G.P., Wang, H., Frydenberg, M., Cunha, G., 2001. The metaplastic effects of estrogen on mouse prostate epithelium: proliferation of cells with basal cell phenotype. Endocrinology 142, 2443-2450.

Aamuelson, S.D. (Ed.), 2007. Textbook of Veterinary Histology. , 1st Edn. Saunders Elsevier, St. Louis, MI, p. 63146.

Shabisgh, A., Tanji, N., D’Agati, V., Burchardt, M., Rubin, M., Goluboff, E.T., Heitjan, D., Kiss, A., Buttyan, R., 1999. Early effects of castration on the vascular system of the rat ventral prostate gland. Endocrinology 140, 1920-1932.

Spix, J.B., 1823. Simiarum Et Vespertilionum Brasiliensium Species Novae: Ou Histoire Naturelle Des Espèces Nouvelles De Singes Et De Chauve-souris Observées Et Recueillies Pendant Le Voyage Dans l'intérieur Du Brésil Execute Par Ordre De S.M Le Roi De Bavière Dans Les Années 1817 1818, 1819, 1820. Francisci Seraphici Hubschmanni, Monaco.

Toma, T., Buzzell, G., 1988. Fine structure of the ventral and dorsal lobes of the prostate in the young adult Syrian hamster, Mesocricetus auratus. Am. J. Anat. 2, 132-140

Vasquez, B., Del Sol, M., 2002. Prostatic complex in the rabbit (Oryctolagus cuniculus). Rev. Chil. Anat. 20, 175-180.

Venable, J.H., Coggeshall, R.A., 1965. A simplified lead citrate stain for use in electron microscopy. J. Cell Biol. 25, 407-408.

Watson, M.L., 1958. Staining tissue section of electron microscopy with heavy metals. J. Biophys. Biochem. Cytol. 4, 475-478.

Weibel, E.R., 1963. Principles and methods for the morphometric study of the lung and other organs. Lab. Invest. 12, 131-155.

Wilson, D.E., Findley, J.S., 1970. Reproductive cycle of a Neotropical insectivorous bat, Myotis nigricans. Nature 225 (5238), 1155.

Wilson, D.E., Findley, J.S., 1971. Spermatogenesis in some Neotropical species of Myotis. J. Mammal. 52 (2), 420-426. 